\title{
医療人育成の現況と課題
}

\author{
片岡仁美
}

\section{岡山大学大学院医歯薬学総合研究科 地域医療人材育成}

キーワード：医学教育，地域医療教育，女性医師支援，プロフェッショナリズム， empathy

\section{Current state and challenges of Japanese medical education}

\section{Hitomi U Kataoka}

Department of Medical Education and Primary Care, Okayama University Graduate School of Medicine, Dentistry and Pharmaceutical Sciences

\section{はじめに}

\section{1．2000年代の医学部卒前・卒後教育の現況}

医療，また医学教育を取り巻く現状は特に2000年代 に入ってから大きな変革の時期に入った ${ }^{11}$. 卒前教育 においては, 2000年 (平成12年)に文部科学省は医学・ 歯学教育の在り方に関する調査研究協力者会議を設 置，同会議が平成13年に公表した報告書「21世紀にお ける医学・歯学教育の改善方策について—学部教育 の再構築のために一」において提示された医学教育モ デル・コア・カリキュラムはその後の医学教育の基本 指針となった ${ }^{2)}$.さらに, 平成 17 年に共用試験実施機 構（平成14年に任意団体として設立後社団法人化）が 中心となり，同年共用試験が正式に導入された。共用 試験は, モデル・コア・カリキュアムに準拠し, 臨床 実習開始前に一定水準以上の学生を臨床実習に参加さ せるために医学系全80大学, 歯学系全27大学29校が協 力して推進する大学間共通の評価システムである。コ ンピューターを用いた客観試験（computer based

平成 24 年 1 月受理

厂700-8558 岡山市北区鹿田町 2-5-1

電話：086-235-6963 FAX：086-235-6963

E-mail :hitomik@md.okayama-u.ac.jp testing, CBT）によって知識の総合的理解度を，客観 的臨床能力試験 (objective structured clinical examination, OSCE) によって態度・基本的臨床技能 を評価するものである，また，平成15年からは「国公 私立大学を通じて，教育の質向上に向けた大学教育改 革の取組を選定し，財政的なサポートや幅広い情報提 供を行う」という目的で一連の good practice (GP) が実施されるようになった。国際的に大学に対する財 源措置が成果・業績志向に変化するなか，平成16年に わが国の国立大学の法人化が行われた ${ }^{3)}$ 。このような 情勢を背景に，教育改革にも競争原理が導入されたと もいえる.

卒後教育についても, 新医師臨床研修制度の導入は, 医師育成の制度の変遷のなかでも特筆すべき出来事と いえよう。平成14年には厚生労働省が臨床研修に関す る法令を制定，平成16年からは同制度が実施された。 昭和 21 年に実地修練制度（いわゆるインターン制度） が導入され，昭和 43 年に同制度が廃止となり卒業後の 2 年間の臨床研修を行うことが努力規定となった歴史 があるが, 実にそれから 36 年ぶりの制度改定であった。 新医師臨床研修制度の導入にあたっては，医師として の人格を涵養し，プライマリケアの基本的な診療能力 を修得するとともに，研修に専念できる環境を整備す

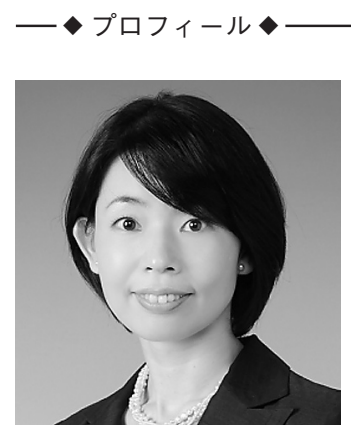

平成 9 年 岡山大学医学部医学科卒業

平成 $9 \sim 11$ 年 公立学校共済組合中国中央病院 研修医

平成15年 岡山大学大学院医学研究科 (内科学第三講座学専攻) 修了

平成15年 岡山大学病院総合診療内科 医員

平成17年 岡山大学医療教育統合開発センター 助手

平成18年 米国ペンシルバニア州トーマスジェファソン大学 客員研究員

平成19年 岡山大学医療教育統合開発センター 助教

平成20年 岡山大学病院卒後臨床研修センター 講師

平成22年 岡山大学大学院医歯薬学総合研究科地域医療人材育成講座 教授

平成12年野口医学研究所より短期米国臨床研修に派遣され，3 月月間の臨床研修を通じ米国の医学教育システム に興味を持つ. 平成18年には留学先で糖尿病性腎症の研究とともに医学教育研究手法を学ぶ. 帰国後は女性医療 人支援取組代表, 卒後臨床研修センター副部門長として医療人育成に関わり, 平成22年より地域医療教育に従事. 
ることを基本的な考え方として, 制度が構築された ${ }^{4)}$. また，米国のマッチング制度を参考にしたマッチング 制度が導入され, 卒業生は卒業大学にかかわらず, 全 国の研修病院を自由に選択できるようになり，大学病 院で研修を行う医師の割合は約70\%から50\%程度にま で減少した5)。

\section{2 . 社会問題となった医師の育成}

Kishiらは，日本のメディアにおける医療に関する 報道で,「医師不足」という単語のメディア出現頻度が 2000年代中盤以降急増していることを報告したが6), 2000 年代に入り,「医師不足」「地域医療の崩壊」が社 会問題化してきた．平成18年には厚生労働省が「医師 の需給に関する検討会報告書」を発表, 地域における 医師確保の対策とともに, 今後増加が見込まれる女性 医師の勤務継続を促す環境整備の必要性が示され た ${ }^{7)}$. また, 新医師確保総合対策が発表され, 地域医 療を担う医師の育成対策として「大学医学部の地域医 療に関する教育の充実, 女性医師に対する復帰支援, 医学部における地域枠の拡充」などが明記された ${ }^{8)}$. 平成19年には緊急医師確保対策が公表され ${ }^{9)}$ ，平成20 年に日本政府は「安心と信頼のビジョン」にて昨今の 医師不足に対し初めて医師不足を認め, これまで長期 間行われていた医学部定員削減政策を方向転換, 医学 部定員を増加させる閣議決定がなされた ${ }^{10)}$.

かくして，地域医療を担う医師の育成を目指した医 学部定員増が急速に進むことになる. 平成18年の新医 師確保総合対策により医師不足が深刻な都道府県につ いて各 10 人，平成 19 年の緊急医師確保対策により全都 道府県について各 5 人, 平成 21 年には地域の医師確保 のための定員増 313 人, 平成 22 年には同じ枠で 59 人の定 員増となった。平成 22 年 4 月時点で全国大学医学部の うち 67 大学で 1,171 人の地域枠が設定されている ${ }^{11)}$.ま た，新医師臨床研修制度については医師不足の悪化の 一因であるとして医道審議会医師分科会臨床研修部会 にて制度見直しの骨子が作成され ${ }^{12)}$,「臨床研修制度の あり方等に関する検討会」で臨床研修制度等の見直し の方向が示された ${ }^{13)}$. 同年 5 月には臨床研修に関する 省令及び通知の一部改正が行われ, 研修の弾力化, 当 該都道府県の募集定員の策定がなされた。

このように，2000年代の医学教育改革と社会情勢は 互いに影響し合い, 大きな潮流となったことがわかる。 これらの事象の一つ一つが検証されるべき内容を含ん でいるが，本稿では特に自らが関与している女性医師
のキャリア支援と地域医療を担う人材の育成について 述べたい。

\section{女性医療人のキャリア支援}

2000年代中盤，医師不足，地域・診療科による医師 の偏在が問題視されるなか, その要因の一つとして, また即効性のある解決策としても注目されたのが女性 医師支援である。文部科学省の「社会的ニーズに対応 した質の高い医療人養成推進プログラム」は，医療人 GP として平成17〜19年に施行されたが，社会に必要 とされる医療人を育てる，という目的が明確であり， 平成19年の医療人 GP のテーマは「女性医師の離職防 止・復職支援」であった。岡山大学を含む 9 大学の取 組が採択され，筆者は医療人 GP の取組担当者として 平成19〜21年の三年間の取組を行った ${ }^{14)}$ 。取組の中心 は11世代を超えたネットワークを通じて経験を共有 し，医師としてのプロフェッショナリズムを次世代に 繋ぐ離職防止，(2)個々のニーズと到達度に合わせた復 職支援，(3)次世代育成の推進である。(1)については， オンラインと顔の見えるネットワークの構築からス夕 ートしたが，現在では学生主導の活動（MUSCAT ジ ユニア）や，平成 23 年度から開始した 1 年生の早期実 習におけるキャリア教育へと発展している。また，(2) については，シミュレーション教育を基軸とした復職 支援・スキル向上トレーニングと，短時間勤務・ワー クシェアなど個々の状況に即した柔軟な働き方を可能 としたキャリア支援制度の構築によって，医療人 GP 終了時で37名の女性医師が復職を果たした。また，(3) については，平成21年のますかっと病児保育ルームの 開所に加え, 次世代育成講演会, 小中学生, 高校生を 対象とした医療体験コースの実施によって次世代を育 てる環境づくりを目指している15).

医療人 GP 終了後は, 地域医療再生計画に基づき, 岡山県から岡山大学への委託事業として活動を継続す ることが可能となった（岡山県女性医師キャリアセン ター運営事業, 名称 MUSCAT プロジェクト). 現在 は，女性医療人のキャリア支援を岡山県全体で展開す ることを目標に活動を継続している．多くの方の御協 力のもと，現時点でキャリア支援制度を利用した医師 は岡山大学病院でのべ 60 名, 地域の医療機関で 7 名に 上る。また，復職支援トレーニングはチームシミュレ ーショントレーニングの他にハワイ大学式シミュレー ショントレーニング, standardized patient の協力によ 
るコミュニケーション研修などバリエーションを増や して展開している。また，復職医師向けの e-ポートフ オリオも開発中である。

本活動は 5 年目となり, 女性医療人の支援は何を目 指すべきか, ということを改めて考えるとき, 離職防 止・復職支援にとどまらない普遍的価值を生み出すべ きだと感じる。女性医師支援が全国で広がった背景に は医師不足，という要因があった。しかしながら，女 性医師が復職し医療現場で活躍することは医師不足の 解消や復職医師のライフサポートのためだけではな く, より良い医療の提供が目的であるはずである. 男 性, 女性, 子育て中, 介護中など様々なバックグラウ ンドを持つ医療人がお互いにプロフェッショナルとし て尊重し合い, 理解し合う職場は, 多様性が尊重され る職場である。そのような職場は, 医療という多様性 に富む現場において, より変化に強くしなやかな力を 発揮できるのではないだろうか. そのためには更に時 間も工夫も必要であるが，岡山大学における女性医師 支援の活動は, 単なる離職防止・復職支援を越えて女 性医療人が生涯研鑽を積み, 社会に貢献する意欲をサ ポートする取組を続けていきたい。

\section{地域医療を担う人材の育成}

\section{1. 米国の事例から学ぶ地域医療教育の役割}

日本では1972年に地域医療を担う人材の育成を目指 した自治医科大学が設立され, 更に昨今の社会情勢を 反映して全国67大学で地域枠が設定された。 また，地 域医療教育を担う部門も各大学で開設されている。一 方，世界でも地域医療を担う人材の育成を目的とした 様々な取組が行われてきた。米国では1970年代より地 域医療を担う人材の育成に取り組んでいるが，単一の 大学で人材育成を行うという方針ではなく，既存の大 学に地域医療人材育成プログラムを設ける方式であ る.この方式は, 我が国における地域枠と類似してい るため, その分析から学ぶべきところは多いと考えら れる。

Howard らは米国における地域医療を担う人材育成 プログラムに関する論文のシステマティックレビュー を行っている. (1)医師不足地域で診療従事する医師を 育成することを目的とする，(2)学生のコホートについ て明確な定義を有する, (3)へき地出身者を入学させる, 臨床実習にへき地医療実習を有するなどのカリキュラ ムの特性がある, という基準に，6つの大学のプログ
ラムが合致した.これらのプログラムの卒業生 1,600 人

(30年間) のうち，へき地で診療従事している医師の 割合は平均53～64\%（へき地の定義によって異なる） であり，プログラム別にみると $26 \sim 92 \%$ どらつきは あるものの，このようなプログラムを有さない大学の 卒業生のうちへき地医療に従事する医師は $3 \%$ あ り，有意に高い比率である。全国の医学部に同様のプ ログラムが存在すれば，その定員が10名ずつとしても へき地医療に従事する医師を約 2 倍に増加させること ができる，としている16).

それでは，どのような因子が「地域医療志向性」を 持つ学生・医師を育てるのだろうか. その一つの可能 性を示しているのが，上述の米国プログラムの中でも 成功例として評価の高いトーマスジェファソン大学の physician shortage area program (PSAP) である. Rabnobitz は, 将来地域医療に従事する学生の予測因 子となるのは何か, 同大学の 20 年間の卒業生に関して 分析している.PSAP には，へき地または小さな町の 出身者で, 将来同様の地域で家庭医療を行う希望を持 ち, 学力的に合格ラインに達している学生が志願する ことができる。入学後は家庭医療学の教員がアドバイ ザーとして定期的にデイスカッションやキャリア相談 を行う。また， 3 年次の地域における家庭医療実習， 4 年次の地域における外来実習が必修となっている。 PSAP では少額の経済的援助も行うが，返還可能な程 度の奨学金である。卒業後は家庭医療の卒後研修プロ グラムの修了と地域での診療従事を求められるが，そ れに対する拘束力はない。それにもかかわらず，卒業 後の地域医療従事の比率は PSAP 卒業生の $87 \%$ と非 常に高い.

本研究では，学生が将来的に地域での診療に従事す る予測因子として，入学時に家庭医療，総合診療など を進路として希望していること，PSAP に所属してい ること, 男性, 国からの奨学金をもらっていること, 4 年次実習で地域に招ける家庭医療実習を選択してい ること，などが挙げられている。上記のうち，入学後 の介入が有効であるのは地域における家庭医療実習の 選択のみであり，実習を選択した学生とそうでない学 生を比較し，地域医療に従事するオッズ比は4.2(95\% CI : 3.2 5.6) である. 入学後の地域での実習が地域 医療に従事するオッズ比を増した点は，教育の重要性 と可能性を示唆している。また，医学部入学早期の地 域における臨床実習経験に関する研究のシステマティ 
ックレビューにおいても, 早期の臨床実習経験は学生 のモチベーション向上, 医師患者関係に対する自信, プロフェッショナリズムの涵養など様々な効果が得ら れることも報告されている ${ }^{17)}$.

\section{2 . 地域医療教育の可能性}

PSAP などの取組で明らかになったように，地域に おける実習の経験は「住民の生活に密着した医療」へ の親和性を増すものであり，プロフェッショナリズム の涵養の機会としても大変貴重である.この観点から， 地域枠学生にとって地域医療実習の機会は大きな意味 を持つことは明らかである.しかし，「住民の生活に密 着した医療」は特定の医師のみが支えるのであろう か? 私は, 地域医療は特定地域の特別な医療ではなく, 皆が理解し支え合うものだと思う。なぜなら，患者中 心の医療を行うという視点に立った時, 患者の家族背 景, 社会的背景を無視して医療を行うことは難しく, 医療機関同士の連携なくして患者を真に支えることは 困難だからである。しかし, 現在の医学教育の枠組み のなかで，患者の背景を含み包括的にとらえる全人的 医療や医療連携を学ぶ機会は十分とはいえないのでは ないか。一方, 地域医療実習は患者の生活の場が実習 の場であり, 全人的医療や医療の連携のあり方を学ぶ 貴重な機会となる. 地域枠学生のみならず, 誰もが共 通して学ぶ機会を得ることが望ましい。

岡山大学では平成 21 年から 1 年次の早期地域医療体 験実習が開始されたが, 初年度は地域枠学生のみが参 加, 翌年は一般学生 1 名参加, という実績であったが, 平成23年度には一般学生14名が参加し, 確実に学生に 浸透してきつつある. また平成 23 年度からは 3 年次に 地域医療体験実習がカリキュラムに組み込まれ, 平成 24 年度からは 4 年次にも行われる。これらによって平 成 22 年度入学以降の学生は全員が地域医療体験実習を 履修することになる。このような機会を有効に活用す ることは地域医療人育成の観点にとどまらず，良き医 師を育てるために有用である。

一方, 卒後臨床研修における地域医療研修は平成 16 年の導入時以来一貫して必修項目となっており, 医師 育成の観点でいかに重要視されているかが示唆され る. 岡山大学病院では, 平成 22 年度より NPO 岡山医 師研修支援機構地域医療病院部会の協力を得て, それ まで岡山市内の診療所中心であった地域医療研修先を へき地も含めて広域とし，地域の医療の中核を担う 中・小規模の病院を実習先に選定した。研修に参加し
た研修医から，地域医療研修に対して高い満足度を得 られたのみならず，研修の受入を頂いた医療機関から の岡山大学病院研修医に対する評価と, 研修の受入に 対しての満足度がいずれも非常に高かった。具体的に は，平成23年度に行った地域医療研修先の責任者16名 に自記式アンケートを送付し（回収率100\%), 研修の 受入を行った感想としては，期待通り以上が 15 名； 94\%（期待以上14名； 56\%，期待通り1名；38\%）で あった。また，岡山大学病院の研修医のやる気につい ては良い以上が 14 名；87\%（大変良い9名；56\%，良 い 5 名；31\%）であった. Rabnobitzらの研究が示す ように, 学生・研修医の時期の地域での診療経験は将 来の地域医療への親和性を増すことから, 研修医の地 域医療研修が有意義なものとなれば，研修医にとって メリットがあるだけでなく，地域への還元につながる 可能性がある。

医療にはscience とともに artの側面が重要であ り，医師のプロフェッショナリズムをどのように涵養 するか, という課題はこれまでも論議されてきた。近 年, 医師のプロフェッショナリズムの一つの指標とし て empathy を評価するスケール (Jefferson scale of empathy：JSE）の有用性が報告されている ${ }^{18)}$. Empathy は「共感」と訳されるが，医療の現場におい ては患者の立場に立ち，コミュニケーションを通じて その背景を含めて理解し, 現状の改善に結びつける, 医療者に不可欠の能力，と定義される ${ }^{19)}$. また, empathy は女性, people-oriented specialty（内科，小 児科, 家庭医療, 精神科など）を専攻する医師で高い ことも報告されている ${ }^{20)}$.さらに, 医師の empathy は 糖尿病患者に打的 $\mathrm{Hb} 1 \mathrm{c}$ や LDL コレステロール 值の改善と相関することも示され, empathy は患者の アウトカムに寄与することが示されている ${ }^{21)}$. JSE 日 本語版は片岡らが作成し, 岡山大学の医学生の empathy は学年を経て上昇していくことを示した ${ }^{22}$. Empathy の中核を成すものは「いかに自分と異なる他 者の視点に立てるか」という概念である。学生, 研修 医にとっての地域医療研修が empathyに及ぼす影響 なども検討していきたい.

\section{まとめ}

医学教育の最近の動向と, その中から特に女性医師 支援，地域医療を担う人材の育成について概説した。 医育機関の役目としても，また個々の医師の役目とし 
ても, 次世代を担う医師の育成は大変重要な課題であ る。特に地域医療教育は, 単に地域に貢献する医師を 育てる，という可能性が期待されるだけでなく，良き 医師を育てるための大きな可能性を包含している。こ のため，新たな試みに対して一つ一つ検証を行いなが ら，より良いアウトカムを目指すことが必要と考えら れる。

\section{文献}

1) Onishi H, Yoshida I : Rapid change in Japanese medical education. Medical Teacher (2004) 26, 403-408.

2 ) 文部科学省高等教育局医学教育課：医学・歯学教育の在り 方に関する調査研究協力者会議報告書. http://www. med. kindai.ac.jp/mm/core/kaizen.pdf（2012年 1 月閲覧）

3 ) 文部科学省高等教育局国立大学法人支援課：国立大学法人 化等. http://www.mext.go.jp/a_menu/koutou/houjin/ 03052701.htm（2012年 1 月閲覧）

4 ) 厚生労働省医政局医事課医師臨床研修推進室：医師臨床研 修制度の変遷. http://www.mhlw.go.jp/topics/bukyoku/ isei/rinsyo/hensen/index.html（2012年 1 月閲覧）

5 ) Nomura K, Yano E, Mizushima S, Endo H, Aoki M, Shinozaki H, Fukui $\mathrm{T}$ : The shift of residents from university to non-university hospitals in Japan : a survey study. J Gen Intern Med (2008) 23, 1105-1109.

6) Kishi Y, Murashige N, KodamaY, Hamaki T, Murata K, Nakada H, Komatsu T, Narimatsu H, Kami M, Matsumura T : A study of the changes in how medically related events are reported in Japanese newspapers. Risk Management and Healthcare Policy (2010) 3, 33-38.

7 ）厚生労働省医政局医事課：「医師の需給に関する検討会報 告書」の公表について. http://www.mhlw.go.jp/shingi/ 2006/07/s0728-9.html（2012年 1 月閲覽）

8 ）厚生労働省医政局指導課：地域医療に関する関係省庁連絡 会議新医師確保総合対策. http://www. mhlw.go.jp/ shingi/2006/12/s1221-16.html（2012年 1 月閲覧）

9 ）政府・与党：平成19年 5 月 31 日緊急医師確保対策につい て. http://www . mhlw.go.jp/topics/bukyoku/isei/ kinkyu/dl/01a.pdf（2012年 1 月閲覧）

10）「安心と希望の医療確保ビジョン」第 9 回会議議事録. http://www-bm. mhlw .go.jp/shingi/2008/05/txt/ s0530-4.txt（2012年 1 月閲覽）

11）文部科学省高等教育局医学教育課：これまでの医学部入学 定員増等の取組について. http://www. mext.go.jp/b_ menu/shingi/chousa/koutou/043/siryo/__icsFiles/ afieldfile/2011/01/18/1300372_1.pdf（2012年 1 月閲覧）

12）厚生労働省医政局医事課医師臨床研修推進室：平成20年 7
月18日医道審議会医師分科会医師臨床研修部会議事録. http://www.mhlw.go.jp/shingi/2008/07/txt/s0718-1.txt (2012年 1 月閲覧)

13）厚生労働省医政局医事課医師臨床研修推進室：平成21年 2 月26日臨床研修制度等に関する意見のとりまとめ（臨床研 修制度のあり方等に関する検討会). http://www. mext. go.jp/b_menu/shingi/chousa/koutou/036/toushin/__ icsFiles/afieldfile/2009/02/26/1247062_1_1.pdf（2012年 1 月閲覽)

14）片岡仁美：女性医師のキャリア支援 H19文部科学省社会 的ニーズに対応した質の高い医療人養成推進プログラム

（医療人 GP）選定「女性を生かすキャリア支援計画」の 活動報告と今後. 岡山医会誌 (2009), 121, 35-40.

15）片岡仁美：岡山発女性医師支援：岡山 MUSCAT の紹介 と実績一トレーニングと柔軟な働き方が可能にした37名の 復職。医学のあゆみ（2010）233，1111-1116.

16) Rabinowitz HK, Diamond JJ, Markham FW, Wortman JR: Medical School Programs to Increase the Rural Physician Supply: A Systematic Review and Projected Impact of Widespread Replication. Acad Med (2008) 83, 235-243.

17) Rabinowitz HK, Diamond JJ, Markham FW, Paynter $\mathrm{NP}$ : Critical factors for designing programs to increase the supply and retention of rural primary care physicians. JAMA (2001) 286, 1041-1048.

18) Dornan T, Littlewood S, Margolis SA, Scherpbier A, Spencer J, Ypinazar V : How can experience in clinical and community settings contribute to early medical education? A BEME systematic review. Med Teach (2006) 28, 13-18.

19) Hojat M, Mangione S, Nasca TJ, Cohen MJM, Gonnella JS, Erdmann JB, Veloski JJ, Magee M: The Jefferson scale of physician empathy : Development and Preliminary psychometric data. Educ Psychol Meas (2001) 61, 349365.

20) Hojat M, Vergare MJ, Maxwell K, Brainard G, Herrine SK, Isenberg GA, Veloski J, Gonnella JS : The devil is in the third year : a longitudinal study of erosion of empathy in medical school. Acad Med (2009) 84, 1182-1191.

21) Hojat M, Louis DZ, Markham FW, Wender R, Rabinowitz C, Gonnella JS: Physicians' empathy and clinical outcomes for diabetic patients. Acad Med (2011) 86, 359-364.

22) Kataoka HU, Koide N, Ochi K, Hojat M, Gonnella JS : Measurement of empathy among Japanese medical students : psychometrics and score differences by gender and level of medical education. Acad Med (2009) 84, 1192-1197. 